\title{
Hemşire ve Ebelerin Kadına Yönelik Eş Şiddeti Olgularını Bildirme Durumları ve İlişkili Faktörler
}

\author{
Nurses and Midwives' Reporting Cases of Intimate Partner Violence and Related Factors
}

\author{
Nazan KOŞTU ${ }^{1}$, Aynur UYSAL TORAMAN²
}

\section{ÖZ}

$\mathrm{Bu}$ çalışma, hemşirelerin ve ebelerin kadına yönelik eş şiddeti olgularını bildirme durumlarını ve bunu etkileyen faktörleri belirlemek amacıyla planlanmış, tanımlayıcı ilişkisel tipte bir çalışmadır. Araştırma, İzmir ve Denizli'de bulunan kamu ve üniversite hastanelerinde Ocak-Mart 2015 tarihleri arasında yürütülmüştür. Araştırmanın evreni 382 hemşire ve ebedir. Araştırmaya katılmayı kabul eden 258 hemşire ve ebe araştırmanın örneklemini oluşturmuştur. Veri toplama formu literatür doğrultusunda araştırmacılar tarafından oluşturulmuştur. Veriler anket yöntemiyle toplanmıştır. Verilerin analizi SPSS 22.0 programında; sayı, yüzde, ortalama ve ki kare testiyle yapılmıştır.

Son bir yılda şiddet olgusuyla karşılaşanların oranı \%37,2, karşılaştığı şiddet olgu sayısı ortalaması ise $7,73 \pm 10,10$ dur. Katılımcıların \%89,5'i şiddet olgusu ile karşılaştığında bildirim yapabileceğini belirtmiştir. Hemşire ve ebelerin şiddet konusunda yeterli bilgisinin olması, kadına yönelik eş şiddeti bildiriminin mesleki uygulamalarının içinde yer alması, çalıştığı serviste kadına yönelik eş şiddeti kayıt formu bulunması, şiddet olgusuyla karşılaşıldığında müdahale etme, adli durumlar ve yasal danışmanlık sağlamak için kullanılabilecek doküman/prosedür/uygulamanın bulunması şiddet olgularını bildirmelerinde istatistiksel olarak anlamlı ilişkisi olan faktörlerdir $(\mathrm{p}<0,05)$.

Çalışmanın sonuçları doğrultusunda; hemşire ve ebelere şiddet bildiriminin önemi ve bildirim yapmalarına ilişkin eğitim programlarının düzenlenmesi, kadına yönelik şiddet olguları ile karşılaşma olasılığı yüksek olan servislerden başlamak üzere konuya duyarlı çalışma ortamlarının yaratılması, gerekli bildirim formlarının ve izlenmesi gereken müdahale düzenlerinin oluşturulması önerilmektedir.

Anahtar Kelimeler: Ebe, Hemşire, Kadına yönelik eş şiddeti, Şiddet bildirimi.

\begin{abstract}
This study was conducted to determine the status of nurses and midwives reporting cases of intimate partner violence and the factors affecting this. This descriptive relational study was carried out in public and university hospitals in Izmir and Denizli between January-March 2015. The universe of the research is 382 nurses and midwives. In the study, 258 nurses and midwives were included in the study. The data collection form was created by the researchers in line with the literature. The data were collected by survey method. Data; In SPSS 22.0 statistics program; average, number, percent and chi-square were evaluated by analysis.

The proportion of those who have experienced violence in the last one year is $37.2 \%$, and the average number of cases experienced violence is $7.73 \pm 10.10$. $89.5 \%$ of the participants stated that they can report when they encounter violence. Having sufficient knowledge of nurses and midwives about violence, involving in the professional practices of the spouse of intimate partner violence, having a registration form for women in the service where she works, intervention in the event of violence, finding documents/procedures/practices that can be used to provide legal advice and legal counseling. It was determined as the factors that had a statistically significant effect in reporting violence cases $(\mathrm{p}<0.05)$.

In line with these results, it is recommended to organize training programs on the importance of reporting violence to nurses and midwives and to make notifications, to create working environments sensitive to the subject, to create necessary notification forms and intervention schemes to be followed, starting from the services that are likely to encounter intimate partner violence.
\end{abstract}

Keywords: Abuse reporting, Intimate partner violence, Midwife, Nurse.

\footnotetext{
* Bu çalışma 17-20 Haziran 2015 tarihinde İzmir/Türkiye'de düzenlenen 1. Ulusal Halk Sağlı̆̆ Hemşireliği Kongresi'nde poster bildiri olarak sunulmuştur.

${ }^{1}$ Öğr. Gör. Dr. Nazan KOŞTU, Halk Sağlığı Hemşireliği, Pamukkale Üniversitesi Sağlık Bilimleri Fakültesi, nkostu@pau.edu.tr, ORCID: 0000-0003-3458-8204

${ }^{2}$ Prof. Dr. Aynur UYSAL TORAMAN, Halk Sağlığı Hemşireliği, Ege Üniversitesi Hemşirelik Fakültesi, aynur.uysal@ege.edu.tr, ORCID: 0000-0001-8176-4042

İletişim / Corresponding Author: $\quad$ Nazan KOŞTU $\quad$ Geliş Tarihi / Received: 24.05.2020 


\section{GİRIS}

Kadına yönelik eş şiddeti; cinsiyet eşitsizliğine dayalı bir insan hakları ihlalidir. Tüm dünyada giderek artan bir halk sağlı̆̆ problemidir ve sürdürülebilir kalkınmaya engeldir. ${ }^{1}$ Dünya Sağlık Örgütüne (DSÖ) (2019) göre; dünyada her üç kadından biri (\%35) hayatının herhangi bir kesitinde fiziksel ya da cinsel şiddete uğramaktadır. Avrupa bölgesinde ise bu oran \%27'dir. Dünya genelinde kadınlar en yaygın olarak (\%30) eşi veya partneri/birlikte yaşadığı kişiden şiddet görmektedir. Dünyada kadın cinayetlerinin üçte biri de (\%38) yine kadınların eşi veya partneri/birlikte yaşadığ 1 kişi tarafindan gerçekleştirilmektedir. ${ }^{1}$ Türkiye'de yapılan ülke tabanlı bir çalışmada kadınların \%36'sı hayatının herhangi bir kesitinde eşi veya birlikte yaşadığı erkekten fiziksel şiddet görmektedir. Son bir yılda ise kadınların eşlerinden fiziksel şiddet görme s1klığg $\% 8$, cinsel şiddet görme siklığ $1 \% 5$, psikolojik şiddet görme sıklığı \%26, ekonomik şiddet görme sıklığı \%15 olarak saptanmıştır. ${ }^{2}$ Türkiye'de yapılan sistematik ve meta analiz çalışmalarında kadınların şiddet görme oranları \%13-78 arasında değişmektedir. ${ }^{3,4} \mathrm{Bu}$ araştırmalar, dünyada olduğu gibi Türkiye'de de şiddete maruz kalan kadınların prevalansının yüksek olduğunu göstermektedir.

Dünyada şiddete maruz kalan kadınların çoğunluğu (\%55-95) bunu açıkla(ya)mamaktadır ya da yardım alabileceği herhangi bir hizmet bulamamaktadır. ${ }^{1}$ Türkiye'de de durum benzerdir. Kadınlar yaşadıkları şiddeti çoğunlukla anlatmamakta ve yalnız göğüslemektedirler. ${ }^{2,3,5}$ Şiddet gören kadınların yardım istemek için bu konuda hizmet veren bir kurum/kuruluşa başvurma oranları son derece düşüktür. ${ }^{2}$

Hem gelişmiş hem de gelişmekte olan ülkelerde kadına yönelik şiddetin yüksek yaygınlığına rağmen şiddet olgularını gerekli kurumlara bildiriminin yetersiz olduğu görülmektedir. Avrupa Birliği ülkelerinde yapılan bir çalışmada (2014), şiddete uğrayan kadınların çok azının kayıtlara geçtiği, kadına yönelik eş şiddeti olgularının sadece \%14'ünün, diğer kadına yönelik şiddet olgularının ise sadece \%13'ünün rapor edildiği bildirilmektedir. ${ }^{6}$ Literatürde özellikle sağlık çalışanlarının şiddet olgusuyla karşılaştığında olguları rapor etme ve bildirmede yaşayabilecekleri bazı sorunlardan ve engellerden bahsedilmektedir. Siiddet olgularını rapor etmenin; şiddete uğramış kadınların güvenliği ve refahı için bir tehdit oluşturabileceği, mağdur kadının yardım isteme ve sağlık profesyonelleriyle şiddet konusunda iletișim kurma konusunda engel oluşturabileceği ifade edilmektedir. ${ }^{7-9}$ Yapılan bir çalışmada, sağlık çalışanlarının çoğu mağdur itiraz ederse eğer şiddet olgusunu rapor etmeyeceğini ve etik kaygılarını dile getirmişlerdir. ${ }^{10}$ Türkiye'de yapılan çalışmalarda da sağlık çalıșanlarının karşılaştıkları şiddet olgularını rapor etme ile ilgili engellerinin olduğunu ve şiddet olgularını gerekli kurumlara bildiriminin yetersiz olduğunu gösteren çalıșmalar bulunmaktadır. ${ }^{11-13}$

Sağl1k sektörü, cinsel ve üreme sağllğ 1 dâhil olmak üzere kapsamlı bir sağlık hizmetleri sunarak ve diğer destek hizmetlerine sevk sağlayarak kadına yönelik şiddetle mücadelede önemli bir rol oynamaktadır. DSÖ, sağlık sektörünün şiddetin tespit edilmesi, diğer sektörlerle iş birliği yaparak önleme politikalarının geliştirilmesi, kadına yönelik şiddetin halk sağlığı sorunu olarak tanınması ve uygun kaynakların tahsis edilmesi için savunuculuk yapmasının gerekliliğine işaret etmektedir. ${ }^{1}$ Sağlık sektörü içerisinde yer alan hemşire ve ebeler çalışma yaşamlarında hizmet verdikleri kadınlarla etkileşimde bulunabilme firsatları olmaktadır. $\mathrm{Bu}$ nedenle şiddete uğrayanları belirleme ve onlara müdahalede bulunmada önemli bir grupturlar. Hemşire ve ebelerin; şiddet yaşayan kadınların belirlenmesi, risk grubunda olan kadınların desteklenmesi ve bakımında önemli rolleri bulunmaktadır. ${ }^{14,15}$ 
Dünyada ve ülkemizde kadına yönelik şiddetle ilgili geniş toplum tabanlı araştırmalar olmasına karşın, sağlık çalışanlarının karşılaştıkları şiddet olgularını bildirmeleri ile ilgili araştırmalar sınırlı sayıdadır. ${ }^{1-3,6,9,10-12,16} \mathrm{Bu}$ nedenle, hemşire ve ebelerin kadına yönelik eş şiddet olgularını bildirme durumlarının değerlendirilmesi amacıyla yapılan bu araştırmanın kadına yönelik şiddetle mücadele çalışmalarına bilgi sağlayacağı düşünülmektedir.

$\mathrm{Bu}$ çalışmanın amacı hemşire ve ebelerin kadına yönelik eş şiddeti olgularını bildirme durumlarını ve bununla ilişkili faktörleri belirlemektir.

\section{MATERYAL VE METOT}

\section{Araştırmanın Tipi}

$\mathrm{Bu}$ çalışma, tanımlayıcı ilişkisel tipte bir araştırmadır.

\section{Araştırmanın Yeri ve Zamanı}

Araştırma, Türkiye'de Ege Bölgesinde İzmir ve Denizli illerinde bulunan dört Kamu, iki Üniversite Hastanesinde OcakMart 2015 tarihlerinde yapılmıştır.

\section{Araştırmanın Evreni ve Örneklemi}

Çalışmanın evrenini İzmir ve Denizli illerinde bulunan altı hastanenin (dört kamu, iki üniversite hastanesi) kadına yönelik eş şiddeti vakalarıyla karşılaşma olasılığı daha yüksek olan Kadın Doğum ve Acil Servislerinde çalışan toplam 382 hemşire ve ebe oluşturmaktadır. Araştırmada örnekleme seçimine gidilmeden evrenin tamamının katılımı hedeflenmiştir. Fakat çalışmaya katılmayı kabul etmeme veya araştırmanın yapıldı sebeplerle 258 hemşire ve ebe araştırmanın örneklemini oluşturmuştur. Araştırmaya katılım oran $1 \% 67,5$ 'tir.

\section{Veri Toplama Araçları}

Veri toplama formu literatür doğrultusunda araștırmacılar tarafından oluşturulmuştur. ${ }^{2,6,9,12,13,16}$ Veri toplama formunda hemşire ve ebelerin sosyodemografik özellikleri (yaş, cinsiyet, medeni durum, eğitim durumu vb.), mesleki özellikleri (unvan, çalıştığı kurum, servis, çalışma yılı vb.) şiddet olguları ile ilgili müdahale ve bildirim durumlarına ilişkin 28 soru bulunmaktadır.

\section{Verilerin Toplanması}

Veriler araştırmacılar tarafından, anket yöntemi ile toplanmıştır. Soruların yanıtlanması 10-15 dakikalık bir süre almıştır.

\section{Verilerin Değerlendirilmesi}

Verilerin analizi SPSS 22.0 (Statistical Package for Social Science; Chicago, IL, USA) programında yapılmıştır. Verilerin değerlendirilmesinde sayı, yüzde, ortalama ve ki kare analizi kullanılmıştır. Sonuçlar \%95 güven aralığında, $\mathrm{p}<0.05$ anlamlılık düzeyinde değerlendirilmiştir.

\section{Araștırma Etik Yönü}

Araştırma için Ege Üniversitesi Tıp Fakültesi Klinik Araştırmalar etik kurul izni (Sayı:70198063-050.06.04), araştırmanın yapıldı ğ İzmir ve Denizli ilindeki dört kamu ve iki üniversite hastanesinden kurum izinleri, katılımcılardan sözel izin alınmıştır. Katılımcilar anket formlarında isim belirtmemişlerdir.

\section{BULGULAR VE TARTIŞMA}

Araştırmaya katılan hemşire ve ebelerin yaş ortalamaları $34,37 \pm 8,43 \quad$ yıldır. Kat1lımc1ların \%65,9'u hemşire, \%34,1'i ebedir. Hemşire ve ebelerin \%67,8'i lisans ve üstü eğitim durumuna sahipken, \%68,6's1 altı yıl ve üstü süredir çalışmaktadır. Hemşire ve ebelerin bulundukları serviste çalışma sürelerinin ortalaması ise $4,41 \pm 4,82$ yıldır (Tablo 1). 


\begin{tabular}{|c|c|c|}
\hline $\begin{array}{l}\text { GÜSBD 2021; 10(1): 11-20 } \\
\text { GUJHS 2021; } 10(1): 11-20\end{array}$ & \multicolumn{2}{|c|}{$\begin{array}{l}\text { Gümüşhane Üniversi } \\
\text { Gümüşhane Universit }\end{array}$} \\
\hline \multicolumn{3}{|c|}{ Tablo 1. Katılımcıların Tanımlayıcı Özellikleri } \\
\hline Değişkenler & Sayı & $\%$ \\
\hline \multicolumn{3}{|l|}{ Yaș grupları } \\
\hline $18-25$ yaş & 52 & 20,2 \\
\hline $26-30$ yaş & 39 & 15,1 \\
\hline $31-40$ yaş & 107 & 41,5 \\
\hline 41 ve üzeri yaş & 60 & 23,2 \\
\hline \multicolumn{3}{|l|}{ Cinsiyet } \\
\hline Kadın & 227 & 88,0 \\
\hline Erkek & 31 & 12,0 \\
\hline \multicolumn{3}{|l|}{ Medeni durum } \\
\hline Evli & 168 & 65,1 \\
\hline Bekâr & 90 & 34,9 \\
\hline \multicolumn{3}{|l|}{ Çalıştığı kurum } \\
\hline Üniversite Hastanesi & 79 & 30,6 \\
\hline Doğum ve Kadın Hast. Hastanesi & 79 & 30,6 \\
\hline Devlet Hastanesi & 100 & 38,8 \\
\hline \multicolumn{3}{|l|}{ Servis } \\
\hline Kadın Doğum Servisi & 124 & 48,1 \\
\hline Acil Servis & 134 & 51,9 \\
\hline \multicolumn{3}{|l|}{ Unvan } \\
\hline Hemşire & 170 & 65,9 \\
\hline Ebe & 88 & 34,1 \\
\hline \multicolumn{3}{|l|}{ Eğitim durumu } \\
\hline Sağllk Meslek Lisesi/Ön lisans & 83 & 32,2 \\
\hline Lisans ve üzeri & 175 & 67,8 \\
\hline \multicolumn{3}{|l|}{ Calısma yılı } \\
\hline $0-5$ y1l & 81 & 31,4 \\
\hline 6 y1l ve üzeri & 177 & 68,6 \\
\hline \multicolumn{3}{|l|}{ Serviste calısma yılı } \\
\hline $0-5$ y1l & 163 & 63,2 \\
\hline 6 yıl ve üzeri & 95 & 36,8 \\
\hline Toplam & 258 & 100,0 \\
\hline
\end{tabular}

Hemşire ve ebelerin \%75,2'si öğrenimleri süresinde kadına yönelik şiddete ilişkin herhangi bir eğitim almamıştır. Katılımcıların sadece \%22,9'u çalışma süresi boyunca kadına yönelik şiddetle ilgili hizmet içi eğitim aldığını belirtmiştir. Şiddetle ilgili hizmet içi eğitim aldığını belirtenlerin de \%54,2'si çalıştıkları hastanede, \%35,6'sı il sağlık müdürlüğünde, \%10,2'si ise katıld1kları sempozyum/kongre gibi etkinliklerde şiddet konusunda eğitimi aldığını ifade etmiştir. Son bir yılda ise katılımcıların \%93,4'ü kadına yönelik şiddetle ilgili herhangi bir eğitim almamıştır. Hemşire ve ebelerin \%63,6'sı kadına yönelik eş şiddetiyle ilgili yeterli bilgisinin olmadığını, \%76,4'ü şiddet konusunun mesleki uygulamaları içerisinde yer alması gerektiğini ifade etmiştir.

Tablo 2. Çalışılan Serviste Kadına Yönelik Eş Şiddetine İlişkin Uygulamalar

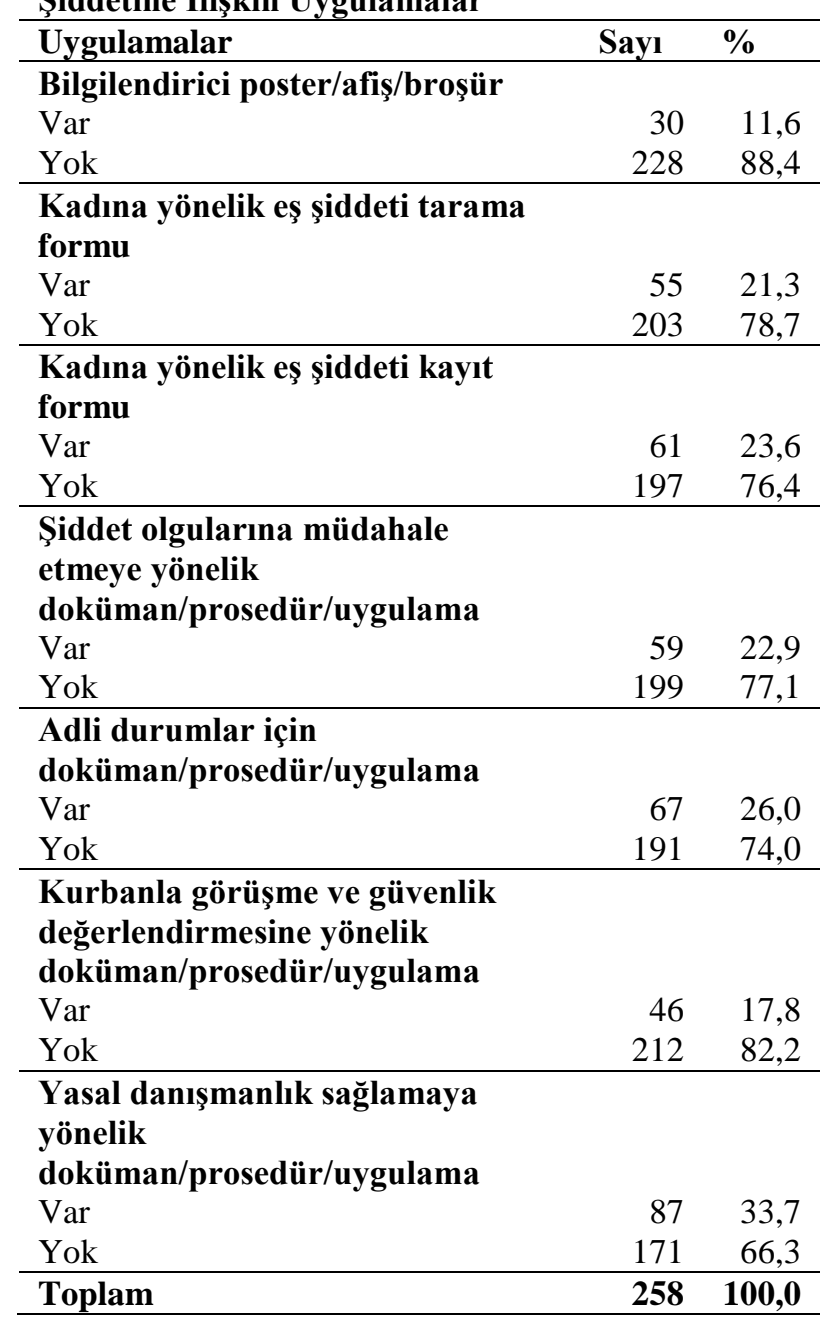

Hemşire ve ebelerin $\% 88,4$ 'ü çalıştı̆g serviste herkesin kolayca görebileceği veya ulaşabileceği şekilde şiddetle ilgili bilgilendirici herhangi bir poster/afiş/broşür bulunmadığını belirtmiştir. Katılımcıların çoğunluğu çalıştıkları serviste kadına yönelik eş şiddetine ilişkin tarama formu $(\% 78,7)$ ve kayıt formunun $(\% 76,4)$ bulunmadığını ifade etmiştir. Hemşire ve ebelerin çoğunluğu şiddet olgularıyla karşılaşıldığında; müdahale etme, kurbanla görüşme ve güvenlik değerlendirmesi yapma, yasal danışmanlık sağlama ve adli durumlar için kullanılabilecek doküman/uygulama/ prosedürün olmadığını belirtmiştir (Tablo 2). 
Tablo 3. Son Bir Yılda Kadına Yönelik Eş Şiddeti Olgusuyla Karşılaşma Durumu

\begin{tabular}{|c|c|c|}
\hline Değișkenler & Sayı & $\%$ \\
\hline \multicolumn{3}{|l|}{ Şiddet olgusuyla } \\
\hline \multicolumn{3}{|l|}{ karşılaşma } \\
\hline Evet, karşılaştım & 96 & 37,2 \\
\hline Hayır, karşılaşmadım & 162 & 62,8 \\
\hline Toplam & 258 & 100,0 \\
\hline \multicolumn{3}{|l|}{ Karşılaştığı şiddet olgu } \\
\hline \multicolumn{3}{|l|}{ sayısı } \\
\hline $1-2$ olgu & 36 & 37,5 \\
\hline $3-4$ olgu & 22 & 22,9 \\
\hline 5 ve üzeri olgu & 38 & 39,6 \\
\hline Toplam & 96* & 100,0 \\
\hline \multicolumn{3}{|l|}{$\begin{array}{l}\text { Karşılaştığı olguyla ilgili } \\
\text { nasıl bir girişimde } \\
\text { bulunduğu }\end{array}$} \\
\hline $\begin{array}{l}\text { Tedavi ve bakım/İleri tıbbi } \\
\text { tanı ve tedaviye } \\
\text { yönlendirme }\end{array}$ & 71 & 22,4 \\
\hline Polise bildirme & 65 & 20,5 \\
\hline $\begin{array}{l}\text { Kadına yönelik aile içi } \\
\text { şiddet formu doldurma }\end{array}$ & 54 & 17,0 \\
\hline $\begin{array}{l}\text { Yasal hakları konusunda } \\
\text { bilgilendirme }\end{array}$ & 38 & 12,0 \\
\hline Psikolojik destek & 37 & 11,7 \\
\hline $\begin{array}{l}\text { Kadın ve çocuk koruma } \\
\text { hizmetlerine yönlendirme }\end{array}$ & 31 & 9,8 \\
\hline Güvenlik planı geliştirme & 14 & 4,4 \\
\hline $\begin{array}{l}\text { Hiçbir şey } \\
\text { yapmama/Kadının şikâyeti } \\
\text { yoktu }\end{array}$ & 7 & 2,2 \\
\hline Toplam & $317 * *$ & 100,0 \\
\hline
\end{tabular}

Son bir y1lda şiddet olgusuyla karşılaşanların oranı \%37,2, karşılaştığ1 şiddet olgu sayısı ortalaması ise 7,73 $\pm 10,10$ dur. Karşılaştığı olguyla ilgili \%22,4'ü tedavi ve bakımını yaptığını, $\% 20,5^{\prime}$ i polise bildirdiğini, \%17,0'si kadına yönelik aile içi şiddet formu doldurduğunu, \%12,0'si yasal hakları konusunda bilgilendirdiğini ifade etmiştir (Tablo 3).

Katılımcıların \%89,5'i şiddet olgusu ile karşılaştı̆̆ında bildirim yapabileceğini belirtirken, \%10,5'i bildirim yapmayacağını belirtmiştir. Bildirim yapmama nedeni olarak \%34,3'ü yasal süreçleri bilmediği, \%20,0'si konuyla uğraşmak istemediği, \%17,1'i sosyal hizmetlerin/polisin konuyla ilgilenmeyeceğini düşündüğü ve \%17,1'i de kadını daha kötü bir duruma sokacağından korktuğu için olduğunu ifade etmiştir (Tablo 4).

Tablo 4. Şiddet Olgusuyla Karşılaşma Durumunda Bildirim Yapmaya Yönelik Bulgular

\begin{tabular}{lrr}
\hline Değişkenler & Sayı & \% \\
\hline Bildirim yapma davranışı & & \\
Bildirim yaparım & 231 & 89,5 \\
Bildirim yapmam & 27 & 10,5 \\
\hline Toplam & $\mathbf{2 5 8}$ & $\mathbf{1 0 0 , 0}$ \\
\hline Bildirim yapmama nedeni & & \\
Yasal süreçleri bilmiyorum & 12 & 34,3 \\
Konuyla uğraşmak istemiyorum & 7 & 20,0 \\
Sosyal hizmetlerin/polisin & 6 & 17,1 \\
konuyla ilgilenmeyeceğini & & \\
düşünüyorum & & \\
Kadını daha kötü duruma & 6 & 17,1 \\
Sokacağımdan korkuyorum & & \\
Kime bildireceğimi bilmiyorum & 3 & 8,6 \\
Zamanım yok & 1 & 2,9 \\
\hline Toplam & $\mathbf{3 5 *}$ & $\mathbf{1 0 0 , 0}$ \\
\hline * Birden çok yanıt verilmiştir & \multicolumn{3}{l}{}
\end{tabular}

Hemşire ve ebelerin şiddet konusunda yeterli bilgisinin olması, kadına yönelik eş şiddeti bildiriminin mesleki uygulamalarının içinde yer alması, çalıştığ 1 serviste kadına yönelik eş şiddeti kayıt formu bulunması, şiddet olgusuyla karşılaşıldığında müdahale etme, adli durumlar ve yasal danışmanlık sağlamak için kullanılabilecek doküman/prosedür/uygulamanın bulunması şiddet olgularını bildirmelerinde istatistiksel olarak anlamlı faktörlerdir $(\mathrm{p}<0.05) \quad$ (Tablo 5).

Hemşireler ve ebeler, şiddete uğramış ve toplumdan izole olmuş kadınların evleri dışında ilişski kurabilecekleri en yakın sağlık profesyonelleri olmaları nedeniyle önemli bir konumdadırlar. $\mathrm{Bu}$ nedenle şiddetle mücadelede anahtar bir roldedirler. ${ }^{15}$

Çalışmamızda hemşire ve ebelerin çoğunluğu öğrenimleri süresinde ve çalışma süreleri içerisinde son bir yılda kadına yönelik şiddete ilişkin herhangi bir eğitim almamıştır. Literatürde konuyla ilgili yapılan çalışmalarda da benzer sonuçlar bulunmaktadır. ${ }^{11-13,17}$ Oysaki kadına yönelik şiddetle mücadelede sağlık çalışanlarının konuyla ilgili eğitilmeleri üzerinde durulması gereken bir konudur. 
Tablo 5. Bazı Değişkenlere Göre Katılımcıların Bildirim Yapma Davranışıyla İlişkili Faktörler

\begin{tabular}{|c|c|c|c|c|c|}
\hline \multirow{3}{*}{ Şiddetle ilgili yeterli bilgi } & \multicolumn{2}{|c|}{ Bildirim yaparım } & \multicolumn{3}{|c|}{ Bildirim yapmam } \\
\hline & \multirow[t]{2}{*}{ Sayı } & \multirow[t]{2}{*}{$\% *$} & \multirow[t]{2}{*}{ Sayı } & \multicolumn{2}{|c|}{$\% *$} \\
\hline & & & & & \\
\hline Evet, yeterli bilgim var & 92 & 97,9 & 2 & 2,1 & $X^{2}=10,971$ \\
\hline Hayır, yeterli bilgim yok & 139 & 84,8 & 25 & 15,2 & $\mathrm{p}=.000$ \\
\hline \multicolumn{6}{|c|}{$\begin{array}{l}\text { Şiddet konusunun mesleki uygulamaları } \\
\text { icerisinde yer alması }\end{array}$} \\
\hline Evet, yer almalıdır & 186 & 94,4 & 11 & 5,6 & $X^{2}=21,189$ \\
\hline Hayır, yer almamalıdır & 45 & 73,8 & 16 & 26,2 & $\mathrm{p}=.000$ \\
\hline \multicolumn{6}{|c|}{ Kadına yönelik eş şiddeti kayıt formu } \\
\hline Var & 59 & 96,7 & 2 & 3,3 & $X^{2}=4,403$ \\
\hline Yok & 172 & 87,3 & 25 & 12,7 & $\mathrm{p}=.024$ \\
\hline \multicolumn{6}{|c|}{$\begin{array}{l}\text { Şiddet olgularına müdahale etmeye yönelik } \\
\text { doküman/prosedür/uygulama }\end{array}$} \\
\hline Var & 57 & 96,6 & 2 & 3,4 & $X^{2}=4,087$ \\
\hline Yok & 174 & 87,4 & 25 & 12,6 & $\mathrm{p}=.029$ \\
\hline \multicolumn{6}{|c|}{$\begin{array}{l}\text { Adli durumlar için } \\
\text { doküman/prosedür/uygulama }\end{array}$} \\
\hline Var & 65 & 97,0 & 2 & 3,0 & $X^{2}=5,404$ \\
\hline Yok & 166 & 86,9 & 25 & 13,1 & $\mathrm{p}=.012$ \\
\hline \multicolumn{6}{|c|}{$\begin{array}{l}\text { Yasal danışmanlık sağlamaya yönelik } \\
\text { doküman/prosedür/uygulama }\end{array}$} \\
\hline Var & 83 & 95,4 & 4 & 4,6 & $X^{2}=4,823$ \\
\hline Yok & 148 & 86,5 & 23 & 13,5 & $\mathrm{p}=.020$ \\
\hline Toplam & 231 & 89,5 & 27 & 10,5 & \\
\hline
\end{tabular}

Sağlık çalışanlarının kadına yönelik şiddet olgularını tespit edebilmesi, olgulara yönelik gerekli müdahaleleri yapabilmesi ve şiddete uğrayan kadınları uygun kurumlara yönlendirebilmesi için bu konuda yeterli eğitim almış olması gerekir. ${ }^{18}$ Yapılan çalışmalarda şiddet olgularına uygun müdahale etmede eğitim programlarının etkili olduğu belirtilmektedir. ${ }^{8,19-23}$

Sağlık çalışanlarında kadına yönelik şiddete karşı duyarlılık oluşturmada, mesleki rol ve yasal sorumlulukları bilmelerini sağlamada mezuniyet öncesi, mezuniyet sonrası ve sürekli eğitim programlarıyla desteklenmeleri önemlidir. ${ }^{8}$ Oysaki çalışmaya katılan hemşire ve ebelerin çoğunluğu kadına yönelik eş şiddetiyle ilgili bilgisinin yetersiz olduğunu ifade etmiştir. Ayrıca çalışmamızda katılımcıların şiddet konusunda yeterli bilgisinin olması şiddet olgularını bildirmede istatistiksel olarak anlamlı faktörlerden birisidir.
Acil servis personeliyle yapılan bir çalışmada katılımcıların çoğunun şiddet kurbanına nasıl profesyonel yaklaşacakları konusunda eğitimsiz oldukları, şiddet kurbanına yardım etmede kendilerini yetersiz hissettikleri bulunmuştur. ${ }^{13}$ Başka bir çalışmada da hemşirelerin çoğunluğu şiddet konusunda yeterli bilgisi olmadığ 1 için şiddete maruz kalan kadınlara müdahale edemeyeceklerini ve müdahale etmede kendilerini yeterli hissetmediklerini belirtmişlerdir. ${ }^{16}$ Kadına yönelik şiddetle mücadelede anahtar rol konumundaki hemşire ve ebelerin çoğunluğunun bilgilerinin yetersiz olması şiddetin saptanmasinda ve bildiriminin yapılmasında önemli bir engel oluşturabilir.

Çalışmamızda hemşire ve ebelerin üçte biri son bir yılda şiddete maruz kalmış bir kadınla karşılaşmış olup, son bir yılda karşılaştıkları şiddet olgu sayısı ortalaması $7,73 \pm 10,10$ dur. Literatürde de sağlik çalışanlarının çoğunluğu şiddete maruz kalmış bir kadınla karşılaşmıştır. ${ }^{13,17,24}$ 
sosyal servislerin konuyla ilgilenemeyeceğini

Çalışmamızda hemşirelerin ve ebelerin şiddete uğramış bir kadınla karşılaştığında en çok tedavi ve bakımını yapma $(\% 22,4)$, polise bildirme $(\% 20,5)$, kadına yönelik aile içi şiddet formu doldurma $(\% 17,0)$, yasal haklar1 konusunda bilgilendirme $(\% 12,0)$, psikolojik destek verme $(\% 11,7)$ şeklindedir. Çalışmaya katılanların yalnızca \%2,2'si hiçbir şey yapmadığını belirtmiştir. Bu bulgu literatürdeki çalışmalarla benzerdir. Yapılan çalıșmalarda sağlık çalıșanlarının şiddet olgularıyla karşılaştıklarında benzer müdahalelerde bulundukları görülmektedir. $^{12,17,25}$ Diğer yandan, bazı çalışmalarda ise hemşirelerin şiddet olgularıyla karşılaştığında nasıl sorular soracağı, ne yapması ya da ne söylemesi gerektiğini bilmede zorlandığı belirtilmektir. ${ }^{25,26,27} \mathrm{Bu}$ nedenle hemşire ve ebelere şiddet olgularıyla karşılaştıklarında nasıl müdahale etmeleri gerektiği, şiddet mağduruyla görüşme yöntemleri, uygun soru sorma teknikleri gibi konularda yeterli eğitim ve destek sağlanmalıdır. Böylece hemşire ve ebeler şiddete maruz kalmış kadınların fiziksel, duygusal ve güvenlik gereksinimlerini karşılamada daha etkin olabilirler. $^{18}$

Çalışmamızda hemşire ve ebelerin çoğunluğu şiddet olgusu ile karşılaştığında bildirim yapabileceğini belirtirken, \%10,5'i bildirim yapmayacağını belirtmiştir. Bildirim yapmama nedeni olarak en çok; yasal süreçleri bilmediği, konuyla uğraşmak istemediği, sosyal hizmetlerin/polisin konuyla ilgilenmeyeceğini düşündüğü ve kadını daha kötü bir duruma sokacağından korktuğu için olduğu ifade edilmiştir. Başka çalışmalarda da benzer bulgular bulunmuştur. Yayla (2009)'nın çalışmasında sağlık çalışanlarının çoğunluğunun kadına yönelik şiddet olgusuyla karşılaştıklarında bildirimde bulunacağı saptanmıștır. ${ }^{28}$ Sarıbıyık (2012)'ın çalıșmasında hemşire ve ebelerin çoğunun kadına yönelik şiddet olgusu ile karşılaşıldığında bildirim yapacağı belirlenmiştir. ${ }^{12}$ Aynı çalışmada bildirim yapmama nedenleri incelendiğinde katılımcıların şiddet gören kadını daha kötü duruma düşüreceğini düşündüğünden, yasal süreçlerle ilgili bilgilerinin yetersizliğinden, düşündüğünden bildirim yapmadığ1 belirtilmiştir. $^{12}$ Kurt ve Gün (2017) çalışmasında aile içi şiddet olgusu veya şüphesi ile karşılaştığında bildirim yapmayı düşünen sağlık personeli oranı $\% 84,1$ 'dir. ${ }^{11}$ Aynı çalışmada sağlık personeli bildirim yapmama nedeni olarak en fazla mağduru şimdiki durumundan daha kötü bir duruma sokuyor olmaktan korkma ve yasal süreçlere ait bilgisinin olmaması gösterilmiștir. ${ }^{11}$ Yapılan bu çalışmalar bizim bulgularımızı destekler niteliktedir. Ancak literatürde şiddet olgusuyla karşılaşıldığında bildirimde bulunma konusunda farklı bulgular da vardır. Barnett ve arkadaşları (2005), sağlık profesyonellerin şüpheli olguların yaklaşık $\% 50$ 'sini bildirmediklerini belirtmektedir. ${ }^{29}$ Davas Aksan ve Aksu (2007)'nun çalışmasında, acil servis personelinin çoğunluğu aile içi şiddet vakalarında adli vaka raporu tutmaya gerek olmadiğını belirtmiştir. ${ }^{13}$ Ramsay ve arkadaşlarının (2012) İngiltere'de sağl1k çalışanlarıyla yaptıkları çalışmada mağdur kadın şiddete uğradığını ortaya koymadığı müddetçe bildirimde bulunulmaması görüşüne her beş sağlık çalışanından biri katılmaktadır. ${ }^{24}$ Smith ve arkadaşlarının (2008) çalışmasında hemşirelerin \%27'si istismardan şüphelendiklerini ancak "yeterli kanıtın bulunmaması" nedeniyle şiddet olgularını rapor etmediklerini belirtmişlerdir. ${ }^{9}$

Çalışmamızda bildirim yapmanın ilişkili olduğu faktörlerden birisi, hemşire ve ebelerin çoğunluğu tarafından şiddete maruz kalanlara bakım vermenin ve kadına yönelik şiddet konusunun hemşirelik görevi/uygulamaları içerisinde yer alması gerektiği görüşüdür. Kadına yönelik şiddet olgusuyla karşılaştığında bildirim yapabileceğini belirten hemşirelerin ve ebelerin çoğunluğu bu konunun mesleki uygulamaları içerisinde yer aldığını ifade etmişlerdir.

İsveç'te birinci basamak sağlik hizmetlerindeki hemşirelerde yapılan bir çalışmada çoğunluğu şiddet konusunda soru sormadıkları veya soru sorma konusunda tereddüt yaşadıklarını söylemişlerdir. Aynı 
çalışmada şiddete maruz kalan kadınları tanılamanın kendi sorumlulukları olmadığı, özellikle hekimler veya sosyal çalışmacıların kadınların ihtiyaçlarını daha iyi karşılayabileceklerini düşündüklerinden soru sorma sorumluluklarını diğer profesyonellere aktarmışlardır. ${ }^{26}$ Yaman Efe ve Taşkın (2012)'ın çalışmasında hemşirelerin neredeyse yarısı aile içi şiddete maruz kalanlara bakmanın hemşirenin görevi olmadiğ 1 görüşündedir. Hemşireler, bu görevin psikiyatristlere veya sosyal hizmet uzmanlarına ait olduğuna inanmaktadır. ${ }^{16}$

Oysaki kadına yönelik eş şiddetiyle mücadele multidisipliner bir iş birliğini gerektirmektedir. Sağlık çalışanları bu disiplinlerden birini oluşturmaktadır. ${ }^{14}$ Çalışmamızdaki hemşire ve ebelerin çoğunluğunun kadına yönelik şiddet konusunun hemşirelik uygulamaları içerisinde yer alması gerektiğini ve şiddete uğramış bir kadınla karşılaştığında bildirimde bulanacağını belirtmesi şiddetle mücadele açısından olumlu bir bulgudur.

Şiddet olgularında bildirim yapmak hem mesleki bir sorumluluk hem de yasal bir zorunluluktur. Öncelikle Türk Ceza Kanunu ve 6284 sayılı Ailenin Korunması ve Kadına Karş1 Şiddetin Önlenmesine Dair Kanunda belirtildiği üzere yasalarımıza göre kadına yönelik şiddet bir suçtur. Gerek uluslararası düzenlemeler gerekse yasalarımız kadına yönelik şiddetle mücadelede ilgili kurum ve kuruluşlara önemli görev ve sorumluluklar yüklemektedir. ${ }^{14} \mathrm{Bu}$ nedenle hemşire ve ebeler, şiddete maruz kalan kadınlara uygun şekilde müdahale etmeli ve olguları gerekli yerlere bildirmelidir.

Sağlık kurumlarında kadına yönelik şiddet ile ilgili prosedür/talimat/uygulamanın varlığı, hemşire ve ebelerin şiddet olgularıyla karşılaştığında izlenilecek yolu göstermesi ve yasal hakların uygulanabilmesi ve şiddet mağduruna uygun müdahaleyi yapabilme açısından oldukça önemlidir. Katılımcıların çoğunluğu çalıştığı serviste kadına yönelik eş şiddetiyle ilgili herhangi bir doküman/prosedür/uygulamanın olmadığını belirtmiştir. Çalışmamızda, çalıştı̆̆ı serviste kadına yönelik eş şiddeti kayı formu bulunması, şiddet olgusuyla karşılaşıldığında müdahale etme, adli durumlar ve yasal danışmanlık sağlamak için kullanılabilecek doküman/prosedür/uygulamanın bulunması şiddet olgularını bildirmelerinde ilişkili olan faktörlerdir.

Kadına yönelik şiddete karşı etkili mücadele stratejilerinden birisi de hemşire ve ebelerin şiddete maruz kalan kadınla karşılaştıklarında görev ve sorumluluklarını yerine getirebilmeleridir. ${ }^{14}$ Hemşire ve ebelerin konu hakkında yeterli bilgilerinin olmaması veya kendilerini konuya müdahale etme konusunda hazir hissetmemelerinin yanında uygun bir çalışma ortamlarının olmamas1, şiddet olgularıla karşılaştıklarında doküman/prosedür/uygulamanın olmamas1 şiddet olgularına müdahale etmelerini engelleyebilir. Yapılan çalışmalarda, sağlık çalışanlarının şiddet olgularına müdahale etmemelerinin kurumsal nedenleri; görüşme için özel bir ortam bulunmaması, kadını sevk edecek sosyal hizmetlerin olmaması, yeterli zamanlarının olmaması ve kadına yönelik şiddeti sorgulamak için bir stratejilerinin olmamas1 olarak belirtilmektedir., ${ }^{9,16,26}$ Davas Aksan ve Aksu (2007)'nun çalışmasında, acil sağlik personelinin çoğunluğunun şiddet olgularında uyulması gereken yasal prosedürler hakkında bilgi sahibi olmadığ1 bulunmuştur. ${ }^{13} \quad$ Yayla (2009)'nın çalışmasında hemşirelerin ve ebelerin neredeyse tamamı şiddet olgularına ilişkin prosedür/talimatın olup olmadığını bilmediğini veya olmadığını belirtmiştir. ${ }^{28}$

Bununla birlikte, kadına yönelik şiddete müdahale etmek sadece fiziksel sağlık problemlerine odakl1 tıbb1 tan1, tedavi ve bakım ile sınırlı değildir. Şiddete maruz kalan kadınlarla görüşme yapma, duygusal destek sağlama, bilgi ve danışmanlık hizmetleri sağlama ve diğer disiplinlerle koordineli çalışmak için yeterli zamana, uygun çalışma ortamına ve şiddet olgularıyla karşılaştıklarında izlenecek stratejilerin/prosedürlerin/uygulamaların varlığına ihtiyaç vardır. Bu nedenle hemşire ve ebelerin çalışma ortamlarında konuyla ilgili uygun ortamların oluşturulması, kadına 
yönelik şiddete uygun müdahale alanlarının sağlanması ve şiddet olgularıyla karşılaştıklarında izlenecek yolları göstermesi olmas1

\section{SONUÇ VE ÖNERILER}

Çalışmamızda hemşire ve ebelerin çoğunluğu öğrenimleri süresinde kadına yönelik şiddete ilişkin herhangi bir eğitim almamıştır. Şiddete uğramış kadınla karşılaştıklarında çoğunlukla tedavi ve bakıma yönelik uygulamalar yaptıkları görülmektedir. Çalışmamızda hemşire ve ebelerin çoğunluğu şiddet olgusu ile karşılaştığında bildirim yapabileceğini belirtmektedir. Araştırmaya katılanlarının çoğunluğu çalıştığı bölümde şiddetle ilgili herhangi bir poster/afiş/form bulunmadığını belirtmiştir. Hemşire ve ebelerin şiddet konusunda yeterli bilgisinin olması, kadına yönelik eş şiddeti bildiriminin mesleki uygulamalarının içinde yer alması, çalıştığı serviste kadına yönelik eş şiddeti kayıt formu bulunması, şiddet olgusuyla karşılaşıldığında müdahale etme, adli durumlar ve yasal danışmanlık sağlamak için kullanılabilecek doküman/prosedür/uygulamanın bulunması şiddet olgularını bildirmelerinde istatistiksel olarak anlamlı ilişkisi olan faktörlerdir.

$\mathrm{Bu}$ sonuçlar doğrultusunda, hemşire ve ebelere kadına yönelik șiddetle mücadele, şiddet bildiriminin önemi ve bildirim yapmalarına ilişkin eğitim programlarının düzenlenmesi, konuyla ilgili hizmet içi eğitimlerin düzenli olarak sağlanması, kadına yönelik şiddet olguları ile karşılaşma olasılığı yüksek olan servislerden başlamak üzere konuya duyarlı çalışma ortamlarının yaratılması, şiddet olgusuyla karşılaştığında müdahale etmeye yönelik prosedürlerin/uygulamaların oluşturulması, çalışma ortamlarında şiddet olgularının gerekli kurumlara bildirilmesinde kullanılacak kadına yönelik şiddet kayıt formu ve bildirim formlarının yaygınlaştırılarak kullanılması, şiddet olgularında gerekli bildirim formlarının ve izlenmesi gereken müdahale düzenlerinin oluşturulması önerilir.
1. World Health Organization. (WHO). (2019). "Respect Women: Preventing Violence Against Women". Geneva: World Health Organization (WHO/RHR/18.19). Licence: CC BY-MC-SA 3.0 IGO. Erişim adresi: https://www.who.int/reproductivehealth/publications/preventin g-vaw-framework-policymakers/en/ (Erişim tarihi: 02.05.2020).

2. Hacettepe Üniversitesi Nüfus Etütleri Enstitüsü. (HÜNEE) (2014). Türkiye'de Kadına Yönelik Aile İçi Şiddet Araştırması (ISBN:978-605-4628-75) (s:83-93). Ankara: Elma Teknik Basım Matbaacılık.

3. Özcan, N.K, Günaydın, S. and Citil, E.T. (2016). "Domestic Violence Against Women in Turkey: A Systematic Review and Meta-Analysis". Arch Psychiatr Nurs, 30, 620-629. doi: 10.1016/j.apnu.2016.04.013

4. Guvenc, G, Akyuz, A. and Cesario, S.K. (2014). "Intimate Partner Violence Against Women in Turkey: A Synthesis of the Literatüre". J Fam Violence, 29 (3), 333-341. doi: 10.1007/s10896-014-9579-4

5. Sen, S. and Bolsoy, N. (2017). "Violence Against Women: Prevalence and Risk Factors in Turkish Sample". BMC Womens Health, 17 (1), 100. doi: 10.1186/s12905-017-0454-3
6. European Union Agency For Fundamental Rights. (FRA). (2014). "Violence Against Women: An EU-Wide Survey". Erișim adresi: http://fra.europa.eu/sites/default/files/fra-2014vaw-survey-main-results_en.pdf (Erişim tarihi: 25.12.2019).

7. Rodriguez, M.A, Craig, A.M, Mooney, D.R. and Bauer, H.M. (1998). "Patient Attitudes about Mandatory Reporting of Domestic Violence. Implications for Health Care Professionals". West J Med, 169 (6), 337-341.

8. Crombie, N, Hooker, L. and Reisenhofer, S. (2017). "Nurse and Midwifery Education and Intimate Partner Violence: A Scoping Review”. J Clin Nurs, 26 (15-16), 2100-2125. doi: 10.1111/jocn.13376.

9. Smith, J, Rainey, S, Smith, K, Alamares, C. and Grogg, D (2008). "Barriers to the Mandatory Reporting of Domestic Violence Encountered by Nursing Professionals". J Trauma Nurs, 15 (1), 9-12. doi: 10.1097/01.JTN.0000315782.20213.72

10. Rodriguez, M.A, McLoughlin, E, Bauer, H.M, Paredes, V. and Grumbach, K. (1999). "Mandatory Reporting of Intimate Partner Violence to Police: Views of Physicians in California". Am J Public Health, 89 (4), 575-578. https://doi.org/10.2105/AJPH.89.4.575 
11. Kurt, G. ve Gün, İ. (2017). "Sağlık Personelinin İstismar, İhmal ve Aile İçi Şiddetle Karşılaşma Durum ve Tutumları”. Adli Tıp Dergisi, 31 (2), 59-67. doi: 10.5505/adlitip.2017.72602

12. Sarıbıyık, M. (2012). Experiences of Doctors, Nurses and Midwives Who Work at The Health Care Centers in The City Center of Malatya, Level of Attitude and Behavior Related to Violence Directed at Women (Unpublished thesis). Institute of Health Sciences of Inonu University, Malatya, Turkey, Erişim adresi: http://hdl.handle.net/11616/1065 (Erișim tarihi: 03.09.2019).

13. Davas Aksan, H.A. and Aksu, F. (2007). "The Training Needs of Turkish Emergency Department Personnel Regarding Intimate Partner Violence". BMC Public Health, 7, 350-359. doi:10.1186/1471-2458-7-350

14. Bahar Özvarış, Ş, Paksoy Erbaydar, N, Balseven Odabaşı, A, Bora, A, Karataş, K, Temüroğlu Sundur, Y. Işıklı, S, Uygur, G. ve Sundur T. (2016). Sağlık Çalışanları Eğitimi Katılımcı Kitabı, Aile İçi Şiddetle Mücadele Projesi. T.C. Aile ve Sosyal Politikalar Bakanlığı, Ankara.

15. International Council of Nurses. (ICN). (2001). Nurses, Always There for You: United Against Violence. International Nurses' Day 2001. Anti-Violence Tool Kit. Genava: Switzerland.

16. Yaman Efe, Ş. and Taşkın, L. (2012). 'Emergency Nurses' Barriers to Intervention of Domestic Violence in Turkey: A Qualitative Study". Sex Disabil, 30, 441-451. doi: 10.1007/s11195-012-9269-1

17. Kıyak, S. ve Akın, B. (2010). "Hemșire ve Ebelerin Kadına Yönelik Şiddet Konusunda Bilgi ve Tutumları". Hemşirelikte Araştırma Geliştirme Dergisi, (12) 2, 5-16.

18. O'Campo, P, Ahmed, F. and Cyriac, A. (2008). The rol of health care professionals in preventing and intervening with intimate partner violence. In: Editors J. KEELING, T. MASON (Ed.). Domestic Violence: A Multi-Professional Approach for Health Professionals (p.107-115). Open University Press, Berkshire, GBR: McGraw-Hill Professional Publishing.

19. Spraque, S. (2019). "A Qualitative Evaluation of the Implementation of an Intimate Partner Violence Education Program in Fracture Clinics". J Fam Violence, 34, 621-630. https://doi.org/10.1007/s10896-019-00052-4

20. Sprague, S, Swaminathan, A, Slobogean, G.P, Spurr, H Arseneau, E, Raveendran, L, Memon, M, Scott, T, Agarwal, G. and Bhandari, M. (2018). "A Scoping Review of Intimate Partner Violence Educational Programs for Health Care Professionals". Women Health, 58, 1192-1206. doi $10.1080 / 03630242.2017 .1388334$

21. Kaplan, S. and Komurcu, N. (2017). "Evaluation of Effectiveness of Health Services Training Given with Different Methods in Combating of Intimate Partner Violence Against Women: A Pilot Study". J Fam Violence, 32, 69-77. doi: 10.1007/s10896-016-9834-y.

22. Sawyer, S, Coles, J, Williams, A. and Williams, B. (2016). "A Systematic Review of Intimate partner Violence Educational Interventions Delivered to Allied Health Care Practitioners". Med Educ, 50 (11), 1107-1121. doi: 10.1111/medu.13108

23. Zaher, E, Keogh, K. and Ratnapalan, S. (2014). "Effect of Domestic Violence Training, Systematic Review of Randomised Controlled Trials". Can Fam Physician, 60, 618624

24. Ramsay, J, Rutterford, C, Gregory, A, Dunne, D, Eldridge, S, Sharp, D. and Feder, G. (2012). "Domestic Violence: Knowledge, Attitudes, and Clinical Practice of Selected UK Primary Healthcare Clinicians". Br J Gen Pract, 62 (602), e647e655. doi:10.3399/bjgp12X654623

25. Haggblom, A.M.E, Hallberg, L.R.M. and Möller, A.R. (2005) "Nurses' Attitudes and Practices Towars Abused Women". Nurs Health Sci, 7 (4), 235-242. doi: 10.1111/j.1442-2018. 2005.00242.x
26. Sundborg, E, Törnkvist, L, Saleh-Stattin, N, Wändell, P. and Hylander, I. (2017). "To Ask, or Not to Ask: The Hesitation Process Described by District Nurses Encountering Women Exposed to Intimate Partner Violence”. J Clin Nurs, 26, 22562265, doi: 10.1111/jocn.12992

27. Uysal Toraman, A. (2015). "Sağlık Kurumlarında Kadına Yönelik Eş Şiddetinin Saptanması: Sağlık Çalışanları Neden Eş Şiddeti Hakkında Soru Sor(m)uyor?". Türkiye Klinikleri J Public Health Nurs-Special Topics, 1 (2), 12-18.

28. Yayla, I.D. (2009). Knowledge Levels and Attitudes of Nurses and Physicians Regarding Violence Aganist Women (Unpublished thesis). Institute of Health Sciences of Marmara University, Istanbul, Turkey. Erişim adresi: https://katalog.marmara.edu.tr/eyayin/tez/T0061522.pdf (Erişim tarihi: 17.09.2019).

29. Barnett, O, Miller-Perrin, C.L. and Perrin, R.D. (2005). Family Violence Across the Lifespan: An Introduction. 2nd ed. Thousand Oaks, CA: Sage. 